\title{
Makey Makey as an Interactive Robotic Tool for High School Students' Learning in Multicultural Contexts
}

\author{
José-Antonio Marín-Marín ${ }^{1}\left(\mathbb{C}\right.$, Rebeca Soler Costa ${ }^{2, *} \mathbb{C}$, Antonio-José Moreno-Guerrero ${ }^{1}(\mathbb{D}$ and \\ Jesús López-Belmonte ${ }^{1}$ (D) \\ 1 Department of Didactics and School Organization, University of Granada, 18071 Granada, Spain; \\ jmarin@ugr.es (J.-A.M.-M.); ajmoreno@ugr.es (A.-J.M.-G.); jesuslopez@ugr.es (J.L.-B.) \\ 2 Department of Didactics and School Organization, University of Zaragoza, 50009 Zaragoza, Spain \\ * Correspondence: rsoler@unizar.es
}

Received: 30 July 2020; Accepted: 5 September 2020; Published: 9 September 2020

\begin{abstract}
Information and communication technologies (ICT) are immersed in the teaching and learning processes. Specifically, educational robotics is a technology with great projection in learning spaces. This educational technology has revealed great potential in educational processes in the scientific literature. In this study, the Makey Makey device has been used to carry out a methodological contrast at the instructional level. The objective of this study is to verify if the use of the Makey Makey robotic device influences various psycho-social and educational dimensions in the subject of physical education. A quasi-experimental research design has been used in a sample of 177 students from secondary education. A questionnaire was used as the data collection instrument. The results show the ratings made by the control group students are lower than those of the experimental group in all dimensions, although there is no relationship of significance in all dimensions. This fact only occurs in motivation, teacher-student, student-content, collaboration, resolution, and teacher-rating dimensions. Conclusions show that the teaching method in which robotics is used leads to more success in the field of physical education if we compared it to the more conventional method. The outstanding data show the teaching-learning process has the highest influence on motivation, teacher-student, student-content, collaboration, resolution, and teacher rating.
\end{abstract}

Keywords: robotics; education; educative technology; educational innovation; active methodology; academic improvements; secondary education; students

\section{Introduction}

The entry into the second decade of the 21st century is clearly defined by the widespread use of technological devices for a variety of activities [1]. This generalization of technology has flooded spaces, such as training, causing the need to adapt from an analogical era to a digital one, where technological tools allow us to cover the basic needs of citizens [2,3].

Focusing our attention in the educational field, information and communication technologies (ICT) have generated a deep revolution due to the constant technological advances and their implications in the teaching-learning processes [4]. In this sense, the incorporation of technologies per se into these processes does not imply educational improvements. There is evidence [5] that possible improvements in learning are determined by how these technologies are applied and their ability to achieve significant learning in a natural and dynamic way. Now more than ever, the importance of the pedagogical approach to the application of ICT in schools cannot be overlooked. From this perspective, an innovative paradigm can be aimed at teaching traditional content through a novel methodological approach that focuses on the search for new content to teach, integrating and combining innovative activities that promote and impact on the empowerment of students, with the intention of adopting a much more 
collaborative, active, and creative [6]. Specifically, recent applications of this new perspective show great impact on how this integrative model of ICT in education can offer many advantages, particularly related to body and musical expression. On the one hand, research shows it attracts the attention of students by connecting with their interests and motivations. On the other hand, it really helps them to integrate knowledge, mimic, kinaesthetic learning in a collaborative and participate way $[7,8]$. In this sense, the multimodal vision defined by [9] as using 'different modes to represent scientific reasoning and findings' opens up the possibility of presenting the same concept in different ways (descriptive, figurative, experimental, kinaesthetic, and mathematical) with a diversity of interactive technologies. In this way, multimodal representations are used to scaffold the construction of understanding, scientific explanations, and reasoning [10], allowing for greater meaning in learning.

From the institutional perspective, teacher training is a fundamental pillar for the inclusion of ICT in schools to be truly successful and generate significant learning. This vision implies a radical change in teaching practice [11,12], making teachers the guides of the teaching-learning process [13] and developing a series of technopedagogical skills to be able to use ICT in the classroom [14-16]. This change requires the support of educational administrations to apply policies that promote the inclusion of ICT in training spaces [17] and allow for a response to the prevailing digital culture. The final aim is for students to be able to integrate and correlate their learning with today's digital world and the new, interconnected world in which they live.

Roughly speaking, the incorporation of ICT in education must follow an interdisciplinary and transversal process that promotes its use as an efficient pedagogical and methodological resource, thus constituting a challenge for the educational system. Students and teachers must be committed to interact with the social and cultural environment in which they work, adopting a new educational approach [18] that allows them to learn to learn, create thinkers, encourage cooperative and collaborative work, and solve problems by developing their capacity for expression and communication [19]. In this sense, among the different technological innovations that can be used in teaching, one that has taken a great leap forward is robotics [20,21].

According to several studies [22-24], robotics has been acquiring more and more importance in educational spaces. Its use is most significantly focused on the secondary education stage. Among the benefits of using robotics as a pedagogical resource [25,26], we may indicate the improvement of autonomy, creativity, attention, and social relations in students. In addition, it generates more motivating learning contexts, so that students can look for solutions and alternatives to the different questions or doubts they may have in class in a self-regulated manner.

From a pedagogical point of view, robotics develops in students the computational thinking that allows them to enhance higher order cognitive processing through abstraction, the use of logical processes, and the application of algorithms [27], providing them with skills in the information and knowledge society. In addition, the use of robotics in teaching involves promoting the power of imagination in students. This allows them to respond to problems that arise with the resources available to them [28]. In addition, it increases their artistic capabilities for robotic design, their manipulative skills for the construction of the robot itself, and cognitive work. This promotes the development of programming [29]. In this way, robotics provides another mode of interaction in the learning of content by students within the multimodal perspective and the use of technological resources for teaching [30].

The virtues of the qualities developed by the inclusion of robotics in student learning processes force teachers to take on new roles in teaching, acting as guides for all instructional actions. These changes have also come from the student, who now develops an active role and promotes his or her own learning [31,32]. These transformations have promoted significant improvements in several aspects related to students, such as motivation [33]; teamwork; commitment to homework; interactions between teachers and speakers, as well as the didactic contents [34]; active and protagonist participation of students [35]; autonomy as a manager and builder of their wisdom [36] and in the positive attitude of students [37] as outstanding academic indicators in the scientific literature. All this has a direct and positive impact on the performance of the conditions shown by students in their daily lives $[37,38]$. 
As a clear consequence of all this, there is an improvement in the scores on assessment tests and in the achievement of objectives and competencies by students $[39,40]$. Due to the potential offered by robotics in the teaching and learning process, each one has been considered as study dimensions. From now on, these are developed in greater depth for a better understanding and structuring of the study (Section 2.3).

The review of scientific works on the implementation of robotics in teaching explains that its use, compared to traditional training methodologies of an expository nature without the use of digital resources, becomes an effective approach to teaching and learning in different subjects and educational levels $[22,23,35,37,40,41]$.

In the specific case of experiments carried out on robotics in the area of physical education at the compulsory secondary education stage, the studies raise the possibility of integrating robotics into this subject through the use of robotic resources with which students interact with robots [41]. In physical education, the use of these robots helps students improve the acquisition of knowledge, increase motivation, and improve attention span, participation, the school climate, and digital competence in students [8]. Furthermore, the scientific literature reflects that the use of robotics in subjects, such as physical education, allows the development of attention, interaction, motivation, and the attraction of students for the learning process [42].

Among the devices, at the robotics level, that can be used in the teaching and learning processes is the so-called Makey Makey. This technological resource was developed by Jay Silver and Eric Rosenbaum from the Massachusetts Technology Laboratory in the United States [43]. The Makey Makey device has an appearance similar to that of a traditional video game console. It is connected to a computer and is conceived as additional hardware, which allows the transfer of data and orders. Thanks to the Makey Makey, users have the opportunity to achieve new interactions with the machine. All this with the purpose of promoting diverse capacities in people, such as creative thinking, imagination, and the ability to design new interactive projects through robotics [44].

Primarily, this technological resource is made up of several components (Figure 1). On the one hand, at the top, there is a USB port for easy connection to the computer. The front part has the necessary means to be able to control the device interactively. On the back, there is the motherboard next to the processor based on the Arduino programming language. On the other hand, there is the wiring and control clips, which are connected in various slots, both on the front and on the back [45-47]. In order to interact with other everyday objects, the Makey Makey components include actuators, sensors, and a processor as a logical part of the device. This contributes to the development of all kinds of instructional activities where the student has a great participation and decision in the formative actions [48].
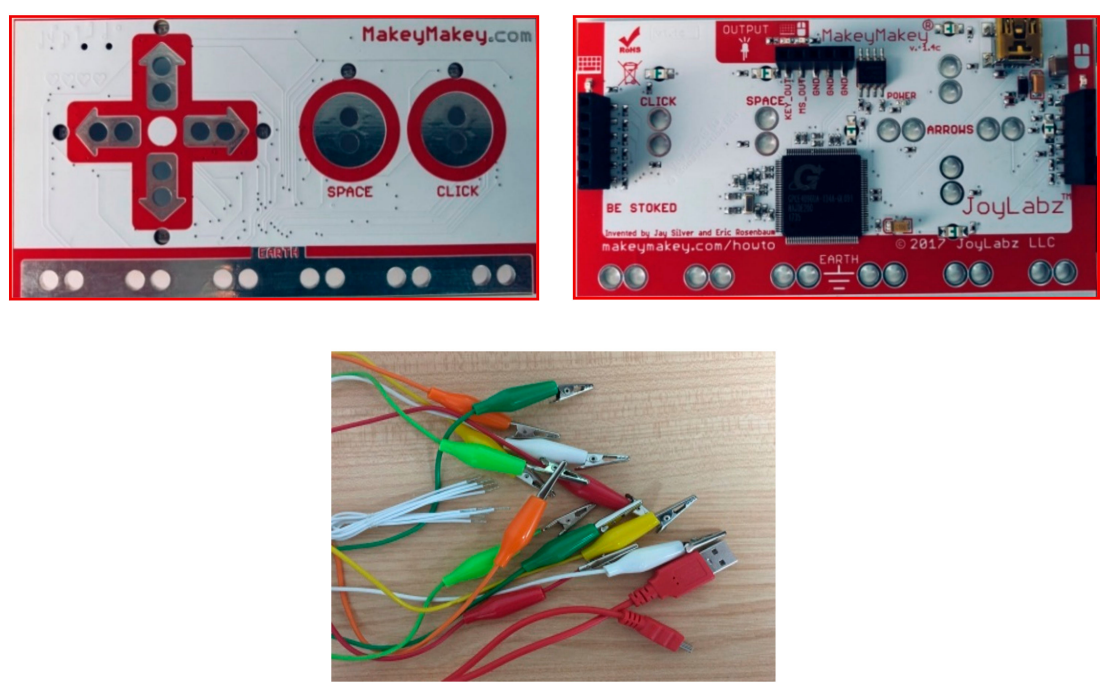

Figure 1. Components of the Makey Makey. 
This technopedagogical resource has several practical implications. Authors, such as [49], assure that the Makey Makey is a resource with high pedagogical potential for use in educational centres, since it promotes the key competence of learning to learn. Its use in teaching-learning processes depends on the proposal made by the teacher, so it requires prior planning [30,31].

Makey Makey, as contrasted in other previous research and with a previous pedagogical project, promotes concentration, motivation, cooperative learning, peer learning, and meaningful learning [50], in addition to improving academic resources and student autonomy [35]. Unlike other robotic tools, the potential of the Makey Makey lies in the possibility of connecting different physical and everyday elements around us to this device. All this favours the interaction of people with the environment, promoting multiple possibilities to promote computational thinking and creativity [51].

\section{Study Objective and Research Questions}

Innovative practices, such as robotics, carried out in the field of education have demonstrated a series of potentialities in the teaching-learning process carried out by students. All this reflects a set of benefits in both psychosocial and academic indicators. These potentialities are focused on the improvement of various academic indicators, such as motivation, interactions, autonomy, collaboration, deepening of the content, problem solving, use of class time, and student ratings [29-40]. In this study, the subject of physical education has been chosen as a case study to work on its contents from a different and innovative perspective. This subject has been identified as one of the most interactive and participatory by students [52]. For this reason, it has been taken to give it a new vision through robotics. All this in order to achieve the potential previously described by the experts.

Therefore, this research focuses on analysing the scope of a training process through robotics through the use of the Makey Makey in the subject of physical education, providing a different didactic process, focused on more conservative physical activities. In order to know the scope of the different potentialities mentioned in robotics, this objective is complemented by the following research question: how does the use of playful interaction in a physical education course affect the different psychosocial and educational dimensions taken into account?

\section{Materials and Methods}

\subsection{Research Design}

The present study has been carried out using a quantitative research methodology through a quasiexperimental design only post-test, under the recommendations of the experts [53,54]. This methodological procedure developed is based on the $t$-test for independent samples. This test allows us to contrast hypotheses referring to the difference between two independent means. This test is ideal to solve the comparison of two different groups of subjects. For example, a group of treated subjects (experimental group) and another of untreated subjects (control group), or a group of subjects subjected to treatment A and another subjected to treatment $B$, as is the case in this study. In the same way, the same investigative structure of two reported studies of impact databases that have used the same methodological approach has been used [55-60].

The choice of this research design has involved the configuration of two group typologies, necessary to carry out the study. The control group has carried out a conservative instructional process, while the experimental group has used robotics as an educational technology for the work of didactic contents. In addition, two study variables have been delimited: the training methodology being independent in nature and the effect derived in the different dimensions analysed being of a dependent nature.

\subsection{Participants}

177 students from an educational centre in southern Spain participated in the study, specifically in the Autonomous City of Ceuta, where there live many cultures as Christians, Muslims, Hebrews, 
and Hindus, working together sharing different point of views and aptitudes. This sample belongs to the educational stage of secondary education. Subjects have been intentionally chosen. Subjects have been intentionally chosen due to the ease of the researchers to access the student sample due to the collaboration of the educational institution with the research team. Therefore, it was decided to choose all the students in each group, in order to obtain the largest number of participants. Recent and impact investigations have determined that the sample size does not affect the performance of this type of methodological experiments at the formative level [61,62].

Socially, the sample is made up of $41.24 \%$ men and $58.76 \%$ women with a mean age of 13 years $(\mathrm{SD}=1.38)$. These participants have been classified into six study groups ( 3 control groups and 3 experimental groups). The students always remained in their natural group at the educational centre in order not to produce a bias in the research when changing students from groups and environments to which they are familiar. Therefore, the natural group to which the student belonged was not altered before experimentation. Furthermore, the methodological treatment has been established at random; that is, the allocation of the natural group of students to the type of study group occurred randomly. In total, the study covered a total of 6 courses of the first level of secondary education. This allowed the configuration of 6 study groups. The groups are made up of three control groups (with a total of 89 participants) and three experimental groups (with a total of 88 participants). The composition of the groups was natural, and the experience was applied to them, and then, the data were collected with a post-test. The experimental group developed a conservative training action and the experimental group developed a formative action with robotics.

\subsection{Study Dimensions}

The dimensions used in this study have been chosen from previous investigations that have analysed the influence of various educational methodologies and technologies on instructional action [55-60,63]. To improve the understanding of the results, a description of the dimensions is set out below: (a) Socio-educational: those items related to sex, age, city, nationality, religion, students' course, and the training methodology used; (b) motivation: these are items related to the level of motivation of the students; (c) interactions: those items related to the different interactions produced in the students (with the teacher, with the contents, and between the students); (d) autonomy: these are items related to the level of autonomy reached by the students; (e) collaboration: those items related to the collaboration and teamwork of the students; (f) in-depth study of the contents: these are items related to the projection level obtained by the contents worked on; $(\mathrm{g})$ problem resolution: those items related to the students' ability to solve the problems encountered; (h) class time: these are items related to the use of time in classroom sessions; (i) ratings: related to the perception of the ratings achieved by the students. These focus on the self-evaluation proposals that the Spanish educational system pursues in the process of evaluating students. In them, the student makes their own objective assessment of their learning process; $(j)$ teacher ratings: are the objective ratings achieved by the students and recorded by the teacher in the different assessment tests.

\subsection{Instrument}

An ad hoc questionnaire has been the instrument used for the data collection process of this investigation. The design of the questionnaire has started from other instruments reported from the expert literature in this field of knowledge $[8,57,59]$. The questionnaire is composed of a total of 14 dimensions and 31 variables. These dimensions are: (a) socio-educational ( 5 variables); (b) motivation (2 variables); (c) autonomy (2 variables); (d) collaboration (2 variables); (e) participation (2 variables); (f) resolution (2 variables); (g) class time (2 variables); (h) concepts (2 variables); (i) scientific data (2 variables); (j) graphics (2 variables); ( $\mathrm{k}$ ) results (2 variables); (l) decision (2 variables), and ( $\mathrm{m}$ ) ratings ( 3 variables). The response format of the various questions follows a Likert scale of 4 values in increasing order of positivity. 
The validation of the questionnaire has been produced by the Delphi method. Eight experts in educational technology intervened in this process. These judges analysed the questionnaire and offered pertinent feedback for its optimization, as well as a positive evaluation $(\mathrm{M}=4.86 ; \mathrm{SD}=0.74 ; \mathrm{min}=1$; $\max =6$ ). The specialists' verdict was statistically analysed, obtaining an adequate degree of relevance and agreement in the observations made (Kappa of Fleiss $=0.84 ; \mathrm{W}$ of Kendall $=0.86$ ). Likewise, an exploratory factor analysis was carried out with the principal components' method. The tests carried out determined dependence between the variables (Bartlett's test of sphericity $=2183.52 ; p<0.001$ ) and a correct sample adequacy (Kaiser-Meyer-Olkin test $=0.83$ ). Other statistics used decreed the reliability of the questionnaire with adequate internal consistency of the established constructs (Cronbach's alpha, $\alpha=0.83$; compound reliability $=0.81$; average variance extracted $=0.8$ ).

\subsection{Procedure}

The researchers maintained a close relationship with the teachers who carried out the intervention with the purpose of advising on the actions to be carried out in each methodological model. A didactic unit of ten sessions was carried out on contents related to physical condition (strength, speed, resistance, and range of motion) in the subject of physical education. The control group followed a conservative training action, that is, without any type of technological resource. The students belonging to this group carried out activities and games aimed at working and developing physical condition using their own training materials (e.g., cones, medicine balls, ropes, TheraBand, rings, mats, fences, fitball, and bosu, among others). All of this was from a traditional perspective of physical education. At no time was a digital resource used. The students limited themselves to carrying out only the activities that the teacher ordered. The experimental group received an innovative training action based on robotics using the Makey Makey device (Figure 2). The different activities and tasks proposed by the teacher were complemented by this robotic tool. This robotic device was complemented with various materials for daily use (fruit, aluminium foil, plasticine, glass of water, and pencil graphite, among others). A fundamental characteristic of the elements used is their ability to conduct electricity. Students connected the aforementioned elements of their surroundings to the Makey Makey device according to their preferences and interests to promote computational thinking, autonomy, participation, interaction, design, and creativity. The students carried out physical activity supplemented with various materials (already mentioned) but robotized. This is a traditional conductive material but connected to the robotic device. All this to energize and innovate in the learning environment and make it more attractive. At a methodological level to work on the various contents that make up the teaching unit, racing games, transport of objects, and people were made. All these activities were carried out through the body itself, the everyday elements of the environment and robotics. In this way, any action of movement or contact of the students with the mentioned material produced a response in a musical application installed on a computer. The pedagogical actions carried out were based on cooperative learning, where the group of students worked as a team and were free to make their own decisions for the benefit of the group. The academic objectives established in this experimentation focused on increasing motivation, interactions, autonomy, collaboration, deepening the content, solving problems, taking advantage of class time, and student ratings. All this through skills, such as computational thinking, creativity, and the design of the materials made by the students. Once all the sessions had been completed, the data were collected with the questionnaire. Subsequently, the data were analysed in depth to extract results that would allow the stated objective to be reached as well as to answer the different research questions. 


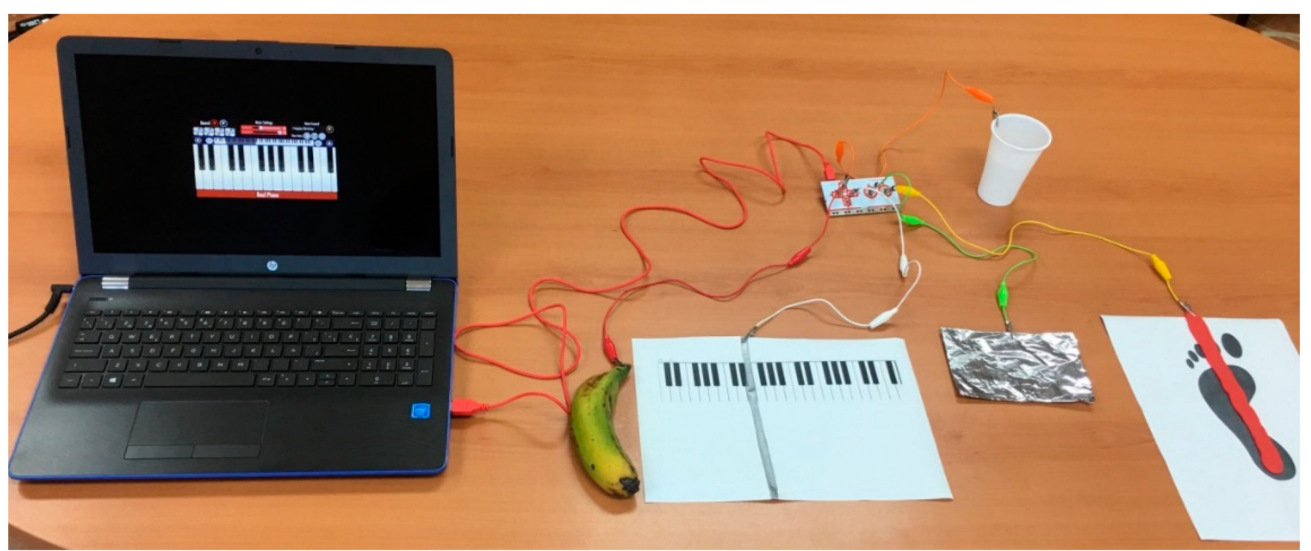

(a)

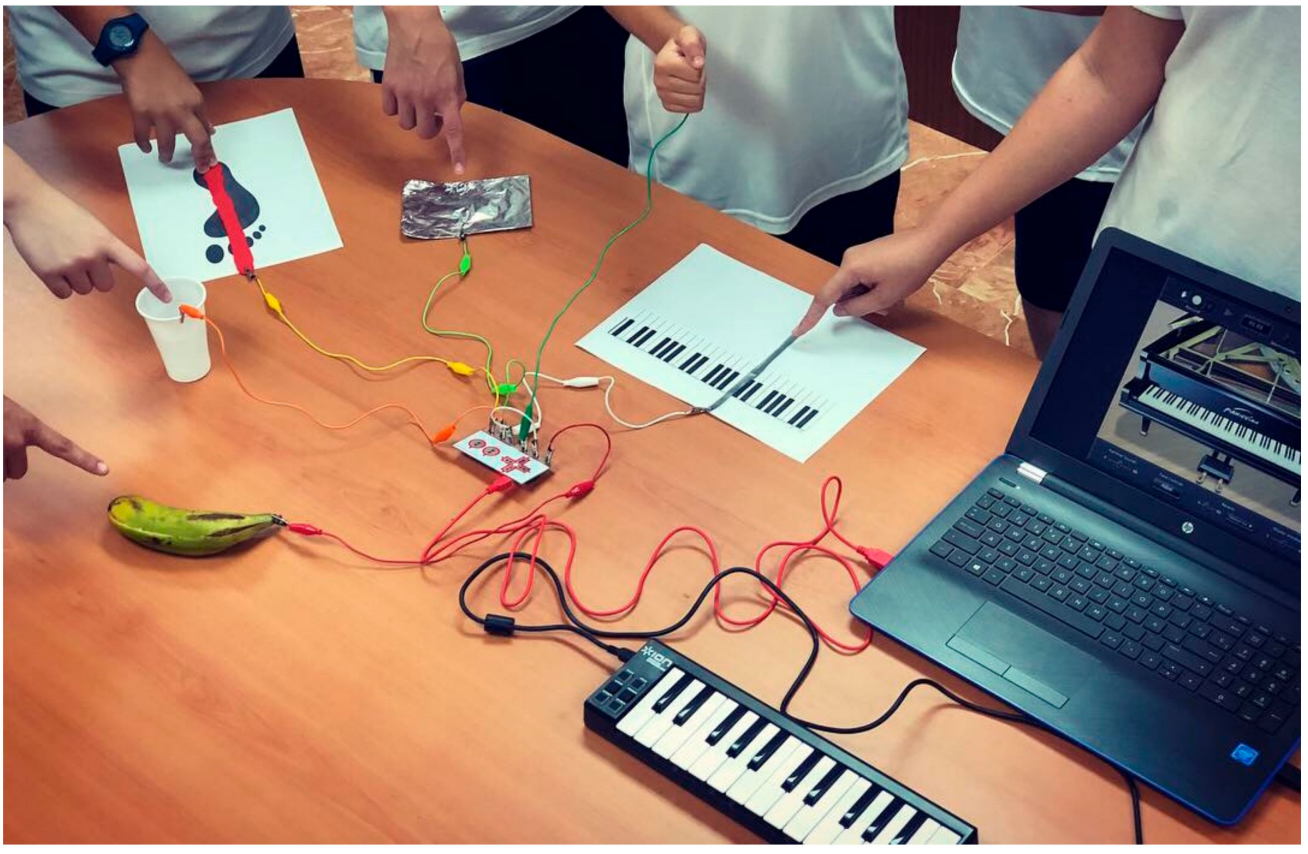

(b)

Figure 2. Items needed to complement the Makey Makey (a); training action with Makey Makey (b).

\subsection{Data Analysis}

The statistical analysis of the collected data was carried out with the Statistical Package for the Social Sciences (SPSS) v25 software. A significance level of $p<0.05$ was established. The statistics used have been the mean (M) and standard deviation (SD). In addition, other more specific tests was carried out to determine the distribution trend, such as Skewness (Skw) and Kurtosis (Kme), the t-Student test $(\mathrm{tn} 1+\mathrm{n} 2-2)$ for comparing the means between groups, Cohen's d, and the biserial correlation (rxy) to obtain the size of the resulting effect.

\section{Results}

In general terms, the statistical data of a descriptive nature provided by the students of compulsory secondary education show differences at the level of means between the control group and the experimental group. In all cases, the sample presents a normal distribution, taking into account the values shown by the statistics of asymmetry and kurtosis, because their values are between \pm 1.96 [64]. In the control group, the averages are around 2.8 points, except for ratings that reach 3 . On the 
other hand, in the experimental group, all the measures of the dimensions studied exceed 3 points. This shows, at first sight, that the ratings of the experimental group are higher than those of the control group in all the dimensions analysed. Furthermore, the experimental group shows less dispersion in responses than the control group, if the standard deviation is taken into account. That is, the students in the experimental group agree more among themselves in the study dimensions than those in the control group. Kurtosis, both in the control group and the experimental group, is platicuric, except in the teacher-student dimension of the experimental group, which is mesocuric (Table 1).

Table 1. Results obtained for the dimensions of study in GC and GC of secondary education.

\begin{tabular}{|c|c|c|c|c|c|c|c|c|c|}
\hline & \multirow[b]{2}{*}{ Dimensions } & \multicolumn{4}{|c|}{ Likert Scale $n(\%)$} & \multicolumn{4}{|c|}{ Parameters } \\
\hline & & None & Few & Enough & Completely & $\mathbf{M}$ & SD & $\mathrm{S}_{\mathrm{kw}}$ & $K_{\text {me }}$ \\
\hline \multirow{11}{*}{ 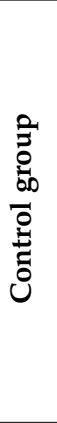 } & Motivation & $12(13.5)$ & $18(20.2)$ & $29(32.6)$ & $30(33.7)$ & 2.87 & 1.03 & -0.477 & -0.936 \\
\hline & Teacher-student & $13(14.6)$ & $18(20.2)$ & $29(32.6)$ & $29(32.6)$ & 2.83 & 1.04 & -0.444 & -0.990 \\
\hline & Student-content & $13(14.6)$ & $13(14.6)$ & $34(38.2)$ & $29(32.6)$ & 2.89 & 1.02 & -0.606 & -0.729 \\
\hline & Student-student & $10(11.2)$ & $23(25.8)$ & $29(32.6)$ & $27(30.3)$ & 2.82 & 0.995 & -0.336 & -0.964 \\
\hline & Autonomy & $12(13.5)$ & $18(20.2)$ & $26(29.2)$ & $33(37.1)$ & 2.90 & 1.05 & -0.505 & -0.987 \\
\hline & Collaboration & $12(13.5)$ & $18(20.2)$ & $27(30.3)$ & $32(36)$ & 2.89 & 1.04 & -0.495 & -0.972 \\
\hline & Deepening & $14(15.7)$ & $16(18)$ & $29(32.6)$ & $30(33.7)$ & 2.84 & 1.06 & -0.487 & -0.993 \\
\hline & Resolution & $12(13.5)$ & $20(22.5)$ & $29(32.6)$ & $28(31.5)$ & 2.82 & 1.02 & -0.398 & -0.986 \\
\hline & Class time & $11(12.4)$ & $20(22.5)$ & $29(32.6)$ & $29(32.6)$ & 2.85 & 1.01 & -0.428 & -0.941 \\
\hline & Ratings a & $7(7.9)$ & $19(21.3)$ & $27(30.3)$ & $36(40.4)$ & 3.03 & 0.971 & -0.602 & -0.736 \\
\hline & Teacher ratings ${ }^{a}$ & $9(10.1)$ & $21(23.6)$ & $31(34.8)$ & $28(31.5)$ & 2.88 & 0.975 & -0.424 & -0.835 \\
\hline \multirow{11}{*}{ 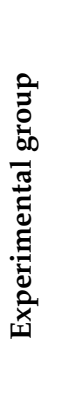 } & Motivation & $4(4.5)$ & $16(18.2)$ & $18(20.5)$ & $50(56.8)$ & 3.30 & 0.924 & -0.985 & -0.261 \\
\hline & Teacher-student & $3(3.4)$ & $14(15.9)$ & $23(26.1)$ & $48(54.5)$ & 3.32 & 0.865 & -0.999 & -0.037 \\
\hline & Student-content & $4(4.5)$ & $17(19.3)$ & $17(19.3)$ & $50(56.8)$ & 3.28 & 0.934 & -0.948 & -0.382 \\
\hline & Student-student & $9(10.2)$ & $17(19.3)$ & $21(23.9)$ & $41(46.6)$ & 3.07 & 1.03 & -0.708 & -0.790 \\
\hline & Autonomy & $11(12.5)$ & $17(19.3)$ & $17(19.3)$ & $43(48.9)$ & 3.05 & 1.09 & -0.687 & -0.957 \\
\hline & Collaboration & $6(6.8)$ & $16(18.2)$ & $17(19.3)$ & $49(55.7)$ & 3.24 & 0.983 & -0.946 & -0.339 \\
\hline & Deepening & $10(11.4)$ & $14(15.9)$ & $24(27.3)$ & $40(45.5)$ & 3.07 & 1.03 & -0.771 & -0.644 \\
\hline & Resolution & $9(10.2)$ & $13(14.8)$ & $18(20.5)$ & $48(54.5)$ & 3.19 & 1.03 & -0.967 & -0.401 \\
\hline & Class time & $9(10.2)$ & $16(18.2)$ & $27(30.7)$ & $36(40.9)$ & 3.02 & 1.01 & -0.671 & -0.684 \\
\hline & Ratings $^{\text {a }}$ & $6(6.8)$ & $15(17)$ & $18(20.5)$ & $49(55.7)$ & 3.25 & 0.974 & -0.984 & -0.286 \\
\hline & Teacher ratings ${ }^{a}$ & $5(5.7)$ & $14(15.9)$ & $22(25)$ & $47(53.4)$ & 3.26 & 0.928 & -0.990 & -0.118 \\
\hline
\end{tabular}

a. Established grade group (None: 1-4.9; Few: 5-5.9; Enough: 6-8.9; Completely: 9-10).

The comparison of means shows, firstly, a higher valuation of all dimensions in the experimental group, compared to the control group. In the control group, the ratings are evenly matched between the dimensions themselves, except for ratings, which stand out considerably from the mean. In contrast, in the experimental group, there is a variety of measures. The dimensions motivation, teacher-student, student-content, collaboration, ratings, and teacher ratings stand out from the total average. These dimensions are the most valued. On the other hand, the dimensions student-student, autonomy, deepening, and class time are below the totalized average (Figure 3).

The value of independence of the results achieved in the teaching and learning method applied for the control group based on the conventional teaching method, with respect to the pedagogical action of the experimental group based on the method based on robotics, has been analysed thanks to the Student $t$ statistic. The data show diversity, as far as the levels of significance are concerned. In this case, the dimensions that are significant are motivation, teacher-student, student-content, collaboration, resolution, and teacher ratings. The rest of the dimensions are not significant to be considered. Of the dimensions that have significance, the level of association, if the values of the biserial correlation are taken into account, is medium, except in the collaboration and resolution dimensions, where the force of association is low. The size of the effect is very low in all the dimensions in which there has been a relationship of significance, with the exception of the ratio of students to content, where the effect size is moderate (Table 2). 


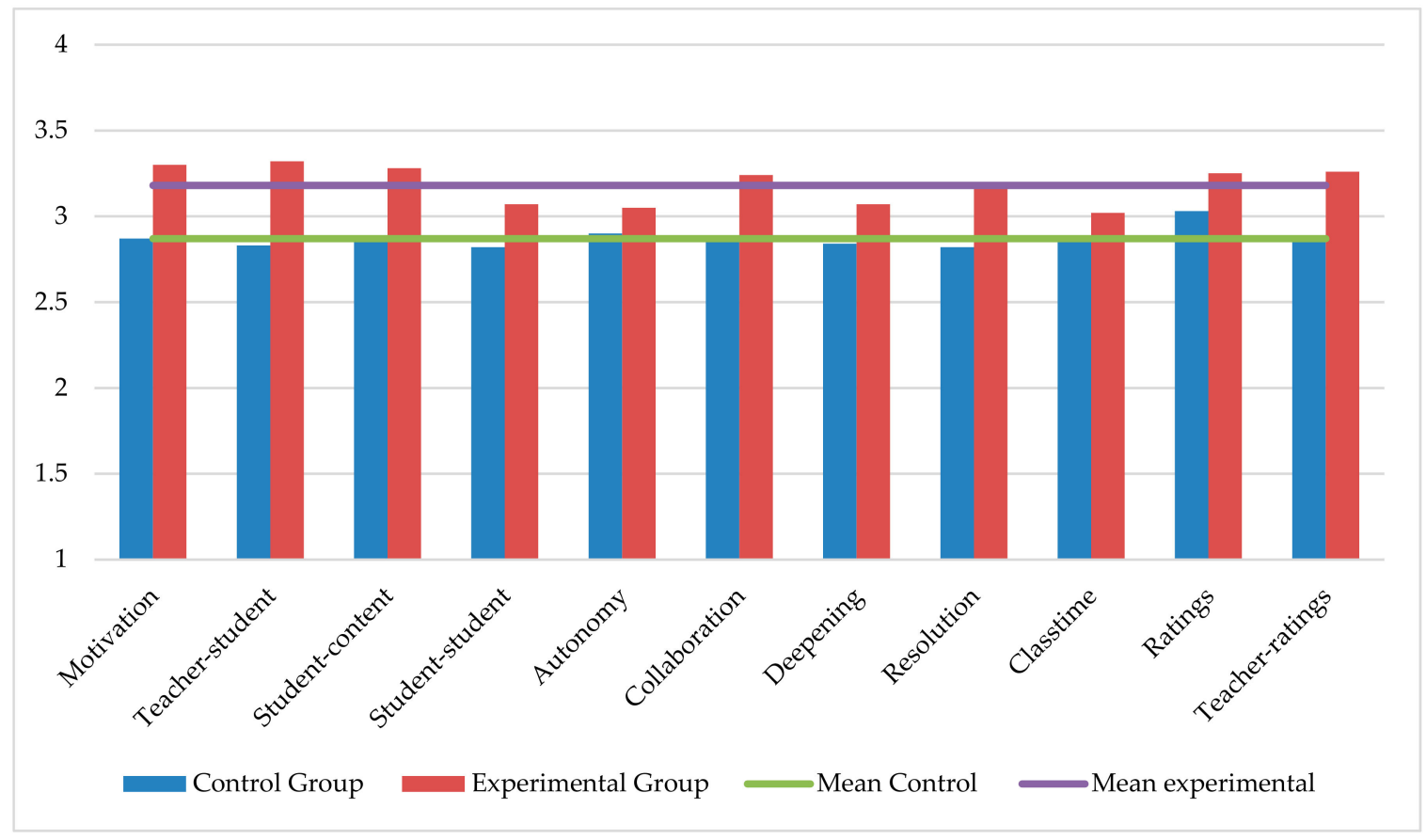

Figure 3. Comparison between control group and experimental group.

Table 2. Study of the value of independence between control group and experimental group.

\begin{tabular}{|c|c|c|c|c|c|}
\hline Dimensions & $\mu(\mathrm{X} 1-\mathrm{X} 2)$ & $t_{n 1+n 2-2}$ & df & $d$ & $\mathbf{r}_{\mathbf{x y}}$ \\
\hline Motivation & $-0.464(2.83-3.30)$ & $-3.124^{* *}$ & 175 & 0.023 & 0.230 \\
\hline Teacher-student & $-0520(2.80-3.32)$ & $-3.582 * *$ & 175 & 0.023 & 0.261 \\
\hline Student-content & $-0.430(2.85-3.28)$ & $-2.895^{* *}$ & 175 & 0.046 & 0.214 \\
\hline Student-student & $-0.282(2.79-3.07)$ & n.s. & - & - & - \\
\hline Autonomy & $-0.180(2.87-3.05)$ & n.s. & - & - & - \\
\hline Collaboration & $-0.385(2.85-3.24)$ & $-2.502 *$ & 175 & 0.017 & 0.186 \\
\hline Deepening & $-0.259(2.81-3.07)$ & n.s. & - & - & - \\
\hline Resolution & $-0.407(2.79-3.19)$ & $-2.605^{* *}$ & 175 & -0.010 & 0.193 \\
\hline Class time & $-0.203(2.82-3.02)$ & n.s. & - & - & - \\
\hline Ratings ${ }^{a}$ & $-0.250(3.00-3.25)$ & n.s. & - & - & - \\
\hline Teacher ratings a & $-0.419(2.84-3.26)$ & $-2.905^{* *}$ & 175 & -0.006 & 0.215 \\
\hline
\end{tabular}

*. Correlation is significant at the 0.05 level; ${ }^{* *}$. Correlation is significant at the 0.01 level; n.s. Correlation not significant; a. established grade group (none: 1-4.9; few: 5-5.9; enough: 6-8.9; completely: 9-10).

\section{Discussion and Conclusions}

The expansion of technology in all areas has meant the transition from an analogical era to a totally digital era [1], where technological tools make it possible to cover everything from basic needs to the development of more complex research tasks in the field of Social Sciences, Health Sciences, Engineering, etc. Specifically, in the educational field, the inclusion of ICT allows us to offer students the presentation and development of contents in a more attractive and motivating way, but it does not always imply an active improvement of students in the teaching-learning processes [4]. Note that the vast majority of authors believe the use of these technological resources should always be accompanied by similar methodological and pedagogical principles and a joint effort by teachers [40]. For this reason, the pedagogical approach to use of ICT in educational institutions remains a key issue. An innovative paradigm and an innovative methodological approach are required to achieve active, social, collaborative, and meaningful learning [6]. It is essential in this innovative approach 
to give students an active and participatory role, allowing them to be the protagonists of their own learning $[7,21]$.

Obviously, achieving these goals implies working on and improving teacher training. To reach these aims a radical change in the teaching practice in which the teacher becomes a guide in the didactic process, promoting the development of ICT and making it easier for students to incorporate new learning are required [18]. This use of ICT implies a commitment by teachers and students to the social and cultural environment in which the activity takes place, adopting an educational approach that favours lifelong learning, learning to learn, and learning to think. Considering all the endless possibilities offered by ICT, robotics in the field of secondary education provides the necessary basis for active, participatory, and social learning [20-24]. Thus, robotics as a pedagogical resource improves autonomy, creativity, attention, and even the development of social relations among students [26]. In addition, from a pedagogical point of view, it also contributes to the development of computational thinking, the improvement of higher order cognitive processing, the use of logical processes and the application of algorithms [27]. In this way, numerous skills and competences are developed in students, such as the power of imagination, artistic abilities, manipulative skills, and so on.

This research has compared, on the one hand, a teaching-learning process through the use of robotics, and on the other hand, the application of classical pedagogical actions. These didactic actions have been developed in the subject of physical education. In this case, the group where the educational experience is developed through robotics presents higher values in all the studied dimensions, if we compared it with the group where a conventional method has been developed. On the other hand, there is more dispersion of response in the control group than in the experimental group. This shows there is more agreement in the group where the educational experience with robotics has been applied than in the other study group. On the other hand, the measures given by the experimental group are more heterogeneous, since there are dimensions that exceed the total average. The most valued dimensions are motivation, teacher-student, student-content, collaboration, ratings, and teacher ratings.

Not all dimensions are significant in the applied study. In this case, those that show levels of significance are motivation, teacher-student, student-content, collaboration, resolution, and teacher ratings. All these dimensions proof to be relevant in the method where the teaching method with robotics is applied with respect to the more conventional teaching method in the development of the educational contents proposed. The strength of association between the dimensions that have been found to be significant has been medium-low. In this case, the strength of association is medium in motivation, teacher-student, student-student, and teacher ratings and is low in collaboration and resolution.

In brief, the teaching method in which robotics is used leads to more success in the field of physical education, compared to the more conventional method. In this case, the most relevant elements and where this teaching-learning process has the greatest influence are motivation, teacher-student, student-content, collaboration, resolution, and teacher rating.

The prospective of this research is quite profitable in the sense that it allows future professionals to acknowledge how robotics can contribute and play its part in education, particularly in the subject of physical education. As said before, this research has been carried out with students of compulsory secondary education, but future research can use these data and apply it to other students' age groups. What is clear is that our main aim lay on the fact of presenting a current, updated, innovative, and useful pedagogical approach to deal with the development of new didactic contents.

However, this research has its own limitations. Primarily, the fact that the study population has its own idiosyncratic characteristics. For this reason, we must be aware of how this sociological environment may condition other research if applied to the same aim and to other population. It is important to be aware of that. In fact, we could not apply sampling techniques in this research, because the access to population was made for convenience. It is comprehensible due to the fact this population group shows difficulties when approaching them. Last but not least, with regards to 
the method and the data collection, we did a great deal, because researchers had to previously train teachers to be able to apply these teaching and learning methods.

With regards to future lines of research, we may state that this didactic method can be applied to other contents and, hence, can be used in other subjects and in other educational stages, with other students of different age. Obviously, this will let us know its viability in other types of contents, and it could also be applied to other ages of students. What is more, it can also be applied to assess the didactic possibilities it offers. These reasons strongly show the need of keeping on with the future lines mentioned as far as they allow the establishment of a comparison of results with other teaching experiences, such as those of the STEM model. So far for the development of teaching and learning processes and with regards to future lines of action, the fact that it can be applied to other contents makes it interdisciplinary, offering endless possibilities for learning and motivation in students. Besides the fact that it can be applied to students of different ages also makes it more attractive and versatile.

Author Contributions: Conceptualization, J.-A.M.-M., and R.S.C.; methodology, J.L.-B.; software, A.-J.M.-G.; validation, A.-J.M.-G.; formal analysis, A.-J.M.-G.; investigation, J.-A.M.-M., R.S.C., A.-J.M.-G., and J.L.-B.; data curation, A.-J.M.-G.; writing-original draft preparation, J.-A.M.-M., R.S.C., A.-J.M.-G., and J.L.-B.; writing-review and editing, J.-A.M.-M., R.S.C., A.-J.M.-G., and J.L.-B.; visualization, J.-A.M.-M., R.S.C., A.-J.M.-G., and J.L.-B.; supervision, J.-A.M.-M., R.S.C., A.-J.M.-G., and J.L.-B. All authors have read and agreed to the published version of the manuscript.

Funding: This research was funded by the project I+D+i OTRI: Active methodologies for learning through technological resources for the development of society (CNT-4315). University of Granada (Spain).

Acknowledgments: To the research group AREA (HUM-672) of the University of Granada (Spain).

Conflicts of Interest: The authors declare no conflict of interest.

\section{References}

1. Hrastinski, S.; Rising, M.E. Communities, networks and ICT professional development across schools in close physical proximity. Technol. Pedagog. Educ. 2020, 29, 219-229. [CrossRef]

2. Bardakci, S.; Ünver, T.K. Preservice ICT teachers' technology metaphors in the margin of technological determinism. Educ. Inf. Technol. 2019, 25, 905-925. [CrossRef]

3. Aznar-Díaz, I.; Trujillo-Torres, J.M.; Romero-Rodríguez, J.M. Estudio bibliométrico sobre la realidad virtual aplicada a la neurorrehabilitación y su influencia en la literatura científica. Rev. Cuba. Inf. Cienc. Salud 2018, 29, 1-11. [CrossRef]

4. Rodríguez-García, A.M.; Cáceres-Reche, M.P.; Alonso-García, S. La competencia digital del futuro docente: Análisis bibliométrico de la productividad científica indexada en Scopus. Int. J. Educ. Res. Innov. 2018, 10, 317-333.

5. Ifinedo, E.; Rikala, J.; Hämäläinen, T. Factors affecting Nigerian teacher educators' technology integration: Considering characteristics, knowledge constructs, ICT practices and beliefs. Comput. Educ. 2020, 146, 103760. [CrossRef]

6. Chen, C.-L.; Wu, C.-C.; Chen, C.-L.; Cheng-Chih, W. Students' behavioral intention to use and achievements in ICT-Integrated mathematics remedial instruction: Case study of a calculus course. Comput. Educ. 2020, 145, 103740. [CrossRef]

7. Aznar, I.; Cáceres, M.P.; Trujillo, J.M.; Romero, J.M. Impacto de las apps móviles en la actividad física: Un metaanálisis. Retos Nuevas Tendencias Educación Física Deporte Recreación 2019, 36, 52-57.

8. López-Belmonte, J.; Pozo-Sánchez, S.; Fuentes-Cabrera, A.; Vicente-Bujez, M.R. Escenarios innovadores en Educación Física: El trabajo de la expresión corporal y musical mediado por la robótica. Retos Nuevas Tend. Educ. Fís. Deporte Recreac. 2020, 38, 567-575.

9. Prain, V.; Waldrip, B. An Exploratory Study of Teachers' and Students' Use of Multi-modal Representations of Concepts in Primary Science. Int. J. Sci. Educ. 2006, 28, 1843-1866. [CrossRef]

10. Murcia, K. Interactive and multimodal pedagogy: A case study of how teachers and students use interactive whiteboard technology in primary science. Aust. J. Educ. 2014, 58, 74-88. [CrossRef]

11. Andyani, H.; Setyosari, P.; Wiyono, B.B.; Djatmika, E.T. Does Technological Pedagogical Content Knowledge Impact on the Use of ICT In Pedagogy? Int. J. Emerg. Technol. Learn. (iJET) 2020, 15, 126-139. [CrossRef] 
12. Zheng, X.; Kim, H.; Lai, W.; Hwang, G.-J. Cognitive regulations in ICT-supported flipped classroom interactions: An activity theory perspective. Br. J. Educ. Technol. 2019, 51, 103-130. [CrossRef]

13. Gemiya, A.G. Factors Affecting the Use of ICT Services in Ethiopia. Int. J. Inf. Commun. Technol. Educ. 2020, 16, 50-60. [CrossRef]

14. Rodríguez-García, A.; Sánchez, F.R.; Ruiz-Palmero, J. Competencia digital, educación superior y formación del profesorado: Un estudio de meta-análisis en la web of science. Pixel BIT Rev. Medios Educ. 2019, 54, 65-82. [CrossRef]

15. López-Belmonte, J.; Pozo-Sánchez, S.; Cabrera, A.F.; Torres, J.M.T. Analytical Competences of Teachers in Big Data in the Era of Digitalized Learning. Educ. Sci. 2019, 9, 177. [CrossRef]

16. Sharma, E. Developing ICT adoption model based on the perceived awareness and perceived usefulness of technology among telecom users. Int. J. Technol. Enhanc. Learn. 2020, 12, 99. [CrossRef]

17. Senkbeil, M.; Ihme, J.M.; Schöber, C. Wie gut sind angehende und fortgeschrittene Studierende auf das Leben und Arbeiten in der digitalen Welt vorbereitet? Ergebnisse eines Standard Setting-Verfahrens zur Beschreibung von ICT-bezogenen Kompetenzniveaus. Z. Erzieh. 2019, 22, 1359-1384. [CrossRef]

18. Aguirre, B.O.-A.; Correa, J.M.; Barragán, A.G.-C. Las TIC en la atención a la diversidad educativa: El caso de la Comunidad Autónoma Vasca. Rev. Educ. Distancia (RED) 2019, 19, 1-21. [CrossRef]

19. Bújez, A.V.; Mohedo, M.T.D. New Challenges for Music Studies in Higher Education. Proc. Soc. Behav. Sci. 2012, 69, 571-578. [CrossRef]

20. Camilleri, P. Minding the Gap. Proposing a Teacher Learning-Training Framework for the Integration of Robotics in Primary Schools. Inform. Educ. 2017, 16, 165-179. [CrossRef]

21. López-Belmonte, J.; Pozo-Sánchez, S.; Cabrera, A.F.; Romero-Rodríguez, J.-M. Análisis del Liderazgo Electrónico y la Competencia Digital del Profesorado de Cooperativas Educativas de Andalucía (España). Multidiscip. J. Educ. Res. 2019, 9, 194-223. [CrossRef]

22. Jung, S.E.; Lee, K.; Cherniak, S.; Cho, E. Non-sequential Learning in a Robotics Class: Insights from the Engagement of a Child with Autism Spectrum Disorder. Technol. Knowl. Learn. 2019, 25, 63-81. [CrossRef]

23. Benitti, F.B.V. Exploring the educational potential of robotics in schools: A systematic review. Comput. Educ. 2012, 58, 978-988. [CrossRef]

24. Zhong, B.; Li, T. Can Pair Learning Improve Students' Troubleshooting Performance in Robotics Education? J. Educ. Comput. Res. 2019, 58, 220-248. [CrossRef]

25. Newton, K.J.; Leonard, J.; Buss, A.; Wright, C.G.; Barnes-Johnson, J. Informal STEM: Learning with robotics and game design in an urban context. J. Res. Technol. Educ. 2020, 52, 129-147. [CrossRef]

26. López-Belmonte, J.L.; Pozo-Sánchez, S.; Vicente-Bújez, M.R.; Díaz-Mohedo, M.T. Herramientas robóticas para la dinamización de nuevos espacios educativos. Campus Virtuales 2019, 8, 63-73.

27. González-Martínez, J.; Minguell, M.E.; Bosch, M.P. ¿Robots o programación? El concepto de Pensamiento Computacional y los futuros maestros. Educ. Knowl. Soc. (EKS) 2018, 19, 29-45. [CrossRef]

28. Noh, J.; Lee, J. Effects of robotics programming on the computational thinking and creativity of elementary school students. Educ. Technol. Res. Dev. 2019, 68, 463-484. [CrossRef]

29. Gummineni, M. Implementing Bloom's Taxonomy Tool for Better Learning Outcomes of PLC and Robotics Course. Int. J. Emerg. Technol. Learn. (iJET) 2020, 15, 184-192. [CrossRef]

30. Scherer, S. Multimodal Behavior Analytics for Interactive Technologies. KI-Künstl. Intell. 2015, 30, 91-92. [CrossRef]

31. Chen, J.C.W.; Lo, K.M.J. From Teacher-Designer to Student-Researcher: A Study of Attitude Change Regarding Creativity in STEAM Education by Using Makey Makey as a Platform for Human-Centred Design Instrument. J. STEM Educ. Res. 2019, 2, 75-91. [CrossRef]

32. Mäkelä, S.; Vellonen, V. Designing for appropriation: A DIY kit as an educator's tool in special education schools. Int. J. Hum.-Comput. Stud. 2018, 118, 14-23. [CrossRef]

33. López-Belmonte, J.; Segura-Robles, A.; Moreno-Guerrero, A.J.; Parra-González, M.E. Machine Learning and Big Data in the Impact Literature. A Bibliometric Review with Scientific Mapping in Web of Sciebce. Symmetry 2020, 12, 495. [CrossRef]

34. Díaz-Lauzurica, B.; Moreno-Salinas, D. Computational Thinking and Robotics: A Teaching Experience in Compulsory Secondary Education with Students with High Degree of Apathy and Demotivation. Sustainability 2019, 11, 5109. [CrossRef] 
35. López-Belmonte, J.; Marín-Marín, J.A.; Soler-Costa, R.; Moreno-Guerrero, A.J. Arduino advances in web of science. A Scientific mapping of literary production. IEEE Access 2020, 8, 128674-128682. [CrossRef]

36. Chaves, I.; Esquivel, J.; Jiménez, A.C.; Sánchez, H. Makey Makey and its Possible Application in Libraries. Ecienc. Inf. 2018, 8, 190-205.

37. Arís, N.; Orcos, L. Educational Robotics in the Stage of Secondary Education: Empirical Study on Motivation and STEM Skills. Educ. Sci. 2019, 9, 73. [CrossRef]

38. Sullivan, A.; Bers, M.U. Investigating the use of robotics to increase girls' interest in engineering during early elementary school. Int. J. Technol. Des. Educ. 2018, 29, 1033-1051. [CrossRef]

39. Del Olmo-Muñoz, J.; Gutiérrez, R.C.; González-Calero, J.A. Computational thinking through unplugged activities in early years of Primary Education. Comput. Educ. 2020, 150, 103832. [CrossRef]

40. López, J.M.S.; Sevillano-García, M.-L.; Vazquez-Cano, E. The effect of programming on primary school students' mathematical and scientific understanding: Educational use of mBot. Educ. Technol. Res. Dev. 2019, 67, 1405-1425. [CrossRef]

41. Ponce, P.; Molina, A.; Lopez-Caudana, E.; Reyes, G.E.B.; Parra, N.M. Improving education in developing countries using robotic platforms. Int. J. Interact. Des. Manuf. (IJIDeM) 2019, 13, 1401-1422. [CrossRef]

42. Hinojo-Lucena, F.J.; Dúo-Terrón, P.; Ramos, M.; Rodríguez-Jiménez, C.; Moreno-Guerrero, A.J. Scientific Performance and Mapping of the term STEM in Education on the Web of Science. Sustainability 2020, 12, 2279. [CrossRef]

43. Jackson, A.; Mentzer, N.; Kramer-Bottiglio, R. Pilot analysis of the impacts of soft robotics design on high-school student engineering perceptions. Int. J. Technol. Des. Educ. 2018, 29, 1083-1104. [CrossRef]

44. Graván, P.R.; Hervás-Gómez, C.; Padilla, A.H.M.; Fernández-Márquez, E. Perceptions about the Use of Educational Robotics in the Initial Training of Future Teachers: A Study on STEAM Sustainability among Female Teachers. Sustainability 2020, 12, 4154. [CrossRef]

45. Chien, L.; Yu, C. Increase in physical activities in kindergarten children with cerebral palsy by employing MaKey-MaKey-based task systems. Res. Dev. Disabil. 2014, 35, 1963-1969.

46. Hagerman, M.S. Les Bricoscientifiques: Exploring the Intersections of Disciplinary, Digital, and Maker Literacies Instruction in a Franco-Ontarian School. J. Adolesc. Adult Lit. 2017, 61, 319-325. [CrossRef]

47. Lee, E.; Kafai, Y.; Vasudevan, V.; Davis, R. Playing in the arcade: Designing tangible interfaces with MaKey MaKey for Scratch games. In Playful User Interfaces; Springer: Singapore, 2014; pp. 277-292.

48. Vega, J.; Plaza, J.M.C. PyBoKids: An Innovative Python-Based Educational Framework Using Real and Simulated Arduino Robots. Electronics 2019, 8, 899. [CrossRef]

49. Fokides, E.; Papoutsi, A. Using Makey-Makey for teaching electricity to primary school students. A pilot study. Educ. Inf. Technol. 2019, 25, 1193-1215. [CrossRef]

50. Lozano, P.A.; Guerrero, B.A.; Gordillo, W.D. Scratch y Makey Makey: Herramientas para fomentar habilidades del pensamiento de orden superior. Redes Ing. 2016, 1, 16-23. [CrossRef]

51. Morais, I.; Bachrach, M.S. Analyzing the Impact of Computer Science Workshops on Middle School Teachers. In Proceedings of the 2019 IEEE Integrated STEM Education Conference (ISEC), Princeton, NJ, USA, 16 March 2019; pp. 57-61. [CrossRef]

52. Ulstad, S.O.; Halvari, H.; Deci, E.L. The Role of Students' and Teachers' Ratings of Autonomous Motivation in a Self-Determination Theory Model Predicting Participation in Physical Education. Scand. J. Educ. Res. 2018, 63, 1086-1101. [CrossRef]

53. Hernández, R.; Fernández, C.; Baptista, M.P. Metodología de la Investigación, 6th ed.; McGraw Hill: Madrid, Spain, 2014; pp. 129-168.

54. Rodríguez, N. Diseños experimentales en educación. Rev. Pedag. 2011, 32, 147-158.

55. Hinojo-Lucena, F.-J.; López-Belmonte, J.; Cabrera, A.F.; Torres, J.M.T.; Pozo-Sánchez, S. Academic Effects of the Use of Flipped Learning in Physical Education. Int. J. Environ. Res. Public Health 2019, 17, 276. [CrossRef]

56. López-Nuñez, J.A.; López-Belmonte, J.; Moreno-Guerrero, A.-J.; Marin-Marin, J.-A. Dietary Intervention through Flipped Learning as a Techno Pedagogy for the Promotion of Healthy Eating in Secondary Education. Int. J. Environ. Res. Public Health 2020, 17, 3007. [CrossRef] [PubMed]

57. López-Nuñez, J.A.; López-Belmonte, J.; Moreno-Guerrero, A.-J.; Pozo-Sánchez, S. Effectiveness of Innovate Educational Practices with Flipped Learning and Remote Sensing in Earth and Environmental SciencesAn Exploratory Case Study. Remote Sens. 2020, 12, 897. [CrossRef] 
58. Pozo-Sánchez, S.; López-Belmonte, J.; Cabrera, A.F.; López-Nuñez, J.A. Gamification as a Methodological Complement to Flipped Learning-An Incident Factor in Learning Improvement. Multimodal Technol. Interact. 2020, 4, 12. [CrossRef]

59. Moreno-Guerrero, A.-J.; Romero-Rodríguez, J.-M.; López-Belmonte, J.; García, S.A. Flipped Learning Approach as Educational Innovation in Water Literacy. Water 2020, 12, 574. [CrossRef]

60. Moreno-Guerrero, A.-J.; García, M.R.; Heredia, N.M.; García, A.M.R. Collaborative Learning Based on Harry Potter for Learning Geometric Figures in the Subject of Mathematics. Mathematics 2020, 8, 369. [CrossRef]

61. Chou, P.-N.; Feng, S.-T. Using a Tablet Computer Application to Advance High School Students' Laboratory Learning Experiences: A Focus on Electrical Engineering Education. Sustainability 2019, 11, 381. [CrossRef]

62. Yilmaz, A.; Soyer, F. Effect of Physical Education and Play Applications on School Social Behaviors of Mild-Level Intellectually Disabled Children. Educ. Sci. 2018, 8, 89. [CrossRef]

63. Parra-González, M.; López-Belmonte, J.; Segura-Robles, A.; Cabrera, A.F. Active and Emerging Methodologies for Ubiquitous Education: Potentials of Flipped Learning and Gamification. Sustainability 2020, 12, 602. [CrossRef]

64. Jöreskog, K.G. Analysis of Ordinal Variables 2: Cross-Sectional Data Text of the Workshop "Structural Equation Modelling with LISREL 8.51"; Friedrich-Schiller-Universität Jena: Jena, Germany, 2001; pp. 116-119.

(C) 2020 by the authors. Licensee MDPI, Basel, Switzerland. This article is an open access article distributed under the terms and conditions of the Creative Commons Attribution (CC BY) license (http://creativecommons.org/licenses/by/4.0/). 